\title{
Good Corporate Governance and Leverage of Financial Performance: Literatur Review
}

\author{
Lailis Syafa'ah \\ Department of Management, STIE Perbanas Surabaya, Surabaya \\ e-mail: lailissyafaah03@gmail.com
}

\begin{abstract}
A company has a main target to make a profit. However, in these years there are some private company and State-Owned Enterprises has financial trouble and suffered financial losses. Some of those financial trouble is caused by chaotic management and high ratio of debt that causing the risk of failed paying. Successful corporation management is strongly related with applying good corporate governance (GCG). This research aim to analyze the impact of good corporate governance (boards of commissioners, boards of independent commissioners, boards of directors, institutional ownerships) as non-financial aspect and leverage as financial aspect of financial performance. This research is a qualitative research using theoretical review and supported by the previous research. There are two theories as the basic theories to observing the previous research which is agency and trade off theory. The result of the analysis of some previous research found some proposition: (1) boards of commissioners has impact to financial performance, (2) boards of independent commissioners has impact to financial performance, (3) boards of directors has impact to financial performance, (4) institutional ownerships has impact to financial performance, and (5) leverage has impact to financial performance.
\end{abstract}

Keywords-GCG, Leverage, Financial Performance.

\section{INTRODUCTION}

$\mathrm{F}$ INANCIAL performance of a corporation is a description about financial condition in a company which analyzed by financial analysis tools, so that the financial condition of that company that reflecting the work performance in certain period can be known [1]. Assessment to financial performance in a company is a one of many ways that conducted by the management to be responsible to company resource usage to the stockholder and investor. Also, financial performance analysis as the tool to do critical assessment process to the financial condition of the company, and giving solution according to the condition in certain period. Financial trouble is still often happening these years. There are some private company and State-Owned Enterprises that experience decreasing financial performance even experienced continuously detriment. Some of those financial trouble are caused by chaotic management and high ratio of debt that causing the risk of failed paying. Chaotic management strongly related to minimum applying corporate governance system. According to Agustiningsih et al. corporate governance is a system that directing and controlling a company in order to make sure that the company management acting in line with stakeholders' interest [2]. Corporate governance is needed to encourage the creation of the efficient, transparent, and consistent marketplace with laws and regulation.

National Committee on Governance Policy Governance released 5 principal GCG for business actor in Indonesia such as: transparency, accountability, responsibility, and fairness [3]. Applying good corporate governance principle can increasing company performance and increased the long-term economic value for the stakeholder and investor. GCG principle is not a rule that must be obeyed nor implemented. Yet, if the company is freely wanted to apply the principle on their business, it will indirectly be increasing their financial performance. The observation of corporate governance in this research is conducted by observing the characteristic of boards of commissioners, boards of independent commissioners, boards of directors, and institutional ownerships.

Boards of commissioners and boards of independent commissioners are wished can increase company's financial performance and help to break the agency problem. Agustiningsih et al., found that boards of commissioners and boards of independent commissioners positively impacted to company's financial performance, whereas the research that conducted by Nurcahya et al. found a different result, it says that boards of commissioners and boards of independent commissioners are not have any impact to financial performance [2], [4].

Boards of director is an organ to the company that have full responsibility to company management. Boards of director that handling well both their job and responsibility will able to take control to company's performance and reduce the risks of company operational which is will impact to company's financial performance. Research conducted by Nurcahya et al., found that boards of director have impact to company's financial performance [4]. Research that conducted by Kusuma and Supatmi in other hand said that boards of director is not have any impact to company's financial performance [5].

Institutional ownership is shareholding that owns by external party such as insurance, bank, and company investor. Shareholding by this other institution expected to give more encouragement to optimized company's performance in some way doing supervising the company management in order to make a good performance. The research conducted by Wijaya et al. and Ratih found that institutional ownership has impact to financial performance, whereas the research from Kusuma and Supatmi founding different result which is: the institutional ownership do not have impact to financial performance [5]-[7]. 
The $1^{\text {st }}$ International Conference on Business and Engineering Management (IConBEM)

February $1^{\text {st }} 2020$, Institut Teknologi Sepuluh Nopember, Surabaya, Indonesia

Another factors that possible to affect financial performance is Leverage. Leverage is a measurement to take a look how big the assets that owned by the company that paid by debt. Use of debt as an additional to fund company assets are expected to increase the company profit, because company assets used by a company activity that can make profit. The bigger usage of Leverage will affect the increase of interest expense. If the interest expense is bigger than the company profit, the company will face the financial trouble that causing decreased of financial performance. Research by Nurcahya et al. said that leverage have an impact to financial performance [4]. Tampubolon in his research found as well same that leverage have impact to financial performance [8]. Research from Abubakar and Makhdalena found that leverage have negative impact to financial performance [9], [10].

According to phenomenon and inconsistently previous research result, the researcher interested to making furthermore research according to the theoretical observation impact of boards of commissaries, boards of independent commissaries, boards of director, institutional ownership and leverage to the company's financial performance.

\section{A. Theoritical Review}

\section{1) Agency Theory}

Agency theory is a theory that can be used to understanding the relation of management and stakeholder. Jensen and Meckling explaining agency relation as "agency relationship as a contract under which or more person (the principals) engage another person (the agent) to perform some service on their behalf which involves delegating some decision-making authority to the agent" [11]. Management as an agent have responsibility to manage the company and optimized the profit of the stakeholder (Principals), as the reward the agent will get compensation according to the contract. Stakeholder as the principal will affected management decision so the management can take the decision that can be profitable for stakeholder. In order to make this contractual relation running well, the stakeholder will be delegated management as the authority, the maker and decision taker and this relation will be controlled in a contract. In fact, some conflict often happens between the management and stakeholder. The management was often founded has another goal that maybe will contradicting with stakeholder.

Tampubolon said that agency theory assumed that the principals wanted biggest and fastest result as their investation, once of them is the increase of dividend from every stock that they have [8]. The agents in the other hand want their interest accommodated with satisfying and biggest compensation and bonus or incentive for the job that they have done. According to Makhdalena quoted from Jensen and Meckling assume that there is natural conflict between the stakeholders and management because there is a way for the management to take any decision to increase their well-being and sacrificing the stakeholders and that conflict called as agency problem [10], [11]. Agency problem is a problem that arise between principals and agents when there is come conflict of interest in agency relationship.

\section{2) Trade-off Theory}

Trade-off Theory is sacrificing one of the benefits by the company in order to increase another benefits aspects. The company that do a loan will sacrifice their income to pay the debt interest. In the other hand, debt interest can be profitable to the company as the reduction of tax that must be paid to the government. Trade-off theory according to Myers is the theory that explained about making decision by a company in decide to use debt or equity as a form of exchange between interest tax shield (tax profit) and company bankruptcy cost [12]. Myer's definition about trade-off theory parallel with definition that was disclosed by Brigham and Houston [13] trade-off theory is a capital structure theory that explained that company exchange the tax benefits that is obtained from funding debt with the problem that caused by bankruptcy risk [13]. According to Myers and Bringham concluded that the trade-off theory is a theory that explained there is positive and negative effect when a company doing a payment on investation by using debt.

The company can be benefited because obtained the tax benefits for interest payment that can reducing the amount of taxes that paid by the company. Yet, beside the benefit as the reducing taxes pay, the debt giving bankruptcy risk to the company. Trade-off theory in capital structure is balancing the sacrifice that was made and the benefits that will obtained as an effect of using debts. Therefore, the company will use debt to the optimal point to maximize company amount. Optimal point to use the debt is when the benefit of the tax from the debt (debt tax shield) is same with the cost caused by financial trouble or bankruptcy. If the benefit that obtained for using debt is bigger, so another more debt is allowed. But then, if the sacrifice that paid is bigger than the benefits, so the company will not be allowed to take another debt. Tradeoff theory showed that the company with higher profit amount will make the higher debt amount as well, because that company can use the beneficial tax more effective [14]. Besides that, the company that have higher operational profits causing financial trouble cost or bankruptcy become lower. So that, trade-off theory predicted positive relations between company and company's financial performance [14].

\section{3) Financial Performace}

Financial performance is a description of financial condition of a company in certain period that obtained as the result of the management's skill to maximize the resource that owned by a company. According to [1] financial performance of a corporation is a description about financial condition in a company which analyzed by financial analysis tools, so that the financial condition of that company that reflecting the work performance in certain period can be known. According to Setiawan financial performance is determination that can measured the success of an organization or company in making profit [15]. Company performance can be determined by financial report analysis using financial ratios. Makhdalena stated that financial performance of a company can be determined using three approach, such as [10]:

1. Profit accounting approach using some measuring tools like, returns on assets, return on equity, earning per share, net assets per share, net profit, return on capital employed. 
The $1^{\text {st }}$ International Conference on Business and Engineering Management (IConBEM)

February $1^{\text {st }} 2020$, Institut Teknologi Sepuluh Nopember, Surabaya, Indonesia

2. Cash flow approach, is the calculation of company's financial performance approach using clean cash flow in a period.

3. Economic value added.

4. Tobin's Q

Assessment to financial performance in a company is a one of many ways that conducted by the management to be responsible to company resource usage to the stockholder and investor. Company's financial performance strongly related to measurement and performance assessment. Performance measurement is a qualification of company's efficiency and effectiveness in operating business in an accountant period. While, performance measurement is used by a company to evaluate and improvement to the company's operational activities. Financial performance analysis also used as a tool to give a solution to those condition in a certain period.

This financial performance assessment is important to the company and investor. For the investor, that information related to financial performance assessment used for asses if they will invest or maintain their investment to that company or looking for another option. Good company's financial performance will make the investor interested to invest to that company. But then, for the company financial performance assessment can be used for:

1. Measured successful conducted company event in certain period.

2. Looking down to whole organization performance.

3. Basic decided company strategy for the future.

4. A guide for a management to take a decision.

5. The basis for determining investment policies to improve company efficiency and productivity.

Research conducted by Abubakar measured financial performance using ROE [9]:

Return on Equity $($ ROE $)=\frac{\text { Earning before interest } \& \text { tax }(\text { EBIT })}{\text { Equity }}(1)$

Musah and Kong measured financial performance using ROA [16]:

Return on Assets $($ ROA $)=\frac{\text { Earning after tax }(\mathrm{EAT})}{\text { Total Assets }}$

4) Boards of Commissioners

Regulation Otoritas Jasa Keuangan (OJK) about directors and boards of commissioner's issuers or public company, defined that boards of commissioners as issuer organ or public company that be in charge to generally a/o specially supervising corresponding to basis budget also giving advice to directors [17]. According to Agustiningsih et al., boards of commissioners is a department that responsible to supervising the implementation of company decisions, so that can be expected can help to break agency problem that happened in company management [2].

Boards of commissioners recruited and dismissed by General Meeting of Shareholder through (RUPS) the transparent processes. Boards of commissioners is a department that officiate, responsible and have an authority to supervising and giving advice to directors and make sure that the company implementing good corporate governance.
Duty and responsibility of boards of commissioners was regulated in Regulation OJK such as [17]:

1. Boards of commissioners officiate to supervising and responsible due the policy and the way management is done, related to issuer or issuer business and giving advice to the directors.

2. In certain condition, boards of commissioners must do yearly RUPS and another RUPS according to their authority.

3. Boards of commissioners must establish audit committee and another committee.

4. Boards of commissioners must evaluate the committee performance that they have made in terms of assisting the implementation of their duties and responsibilities at the end of each financial year.

Boards of commissioners cannot take place in taking company operational decision. Komite Nasional Kebijakan Governance explained the principals that must be fulfilled by boards of commissioners that make their duty and responsibility running well and effective such as [3]:

1. Boards of commissioners' composition must make possibility of making effective, right, and fast decision, and can act independently.

2. Boards of commissioners' members must be professional, means having integrity and skills so can run their function as well including to make sure that directors already noticed every stakeholder interest.

3. The function of supervising and advising by the boards of commissioners including preventive measure, improvement, to the temporary discharging.

In the research that conducted by Wijaya et al. boards be measured with how many members of boards of commissioners that owned by the company [6]. About the number of boards of commissioners that owned in the company was determined in OJK Regulation No. 33/PJOK.04/2014 that the boards of commissioners at least have two members, which is one of them is an independent commissioner [17]. One of those members must be appointed as president commissioner. Boards of commissioners measured by how many commissioners that owned by the company.

\section{Boards of Commissioners $=$ Number of Commissioners Members}

\section{5) Boards of Independent Commissioners}

Regulation OJK about directors and boards of commissioner's issuers or public company, defined that independent commissioner is the member of boards of commissioners from beyond issuer and public company and completed the requirements as the independent commissioners such as [17]:

1. Independent commissioner is not the person who work or have authority and responsibility to plan, lead, control, or supervising issuer or public company activities in last 6 months, except for re-appointment as issuer or public company independent commissioner to the next period.

2. Independent commissioners have no both directly or indirectly stock to the issuer or public company. 
The $1^{\text {st }}$ International Conference on Business and Engineering Management (IConBEM)

February $1^{\text {st }} 2020$, Institut Teknologi Sepuluh Nopember, Surabaya, Indonesia

3. Independent commissioner has no affiliation relation to issuer or public company, member of boards of commissioners, members of directors, or major shareholder in that issuer or public company.

4. Independent commissioner has no business relation both directly or indirectly that related to issuer or public company business activity.

Boards of independent commissioners in the company has neutral function, where the independent commissioners have duties and responsibilities as supervisor after boards of commissioners. Boards of commissioners in the company is not allowed to stand in any party, so that their existence can reducing misappropriation that conducted by management and can give more value to all stakeholder in the company. The existence of independent commissioners also expected to minimize the agency problem that appear between management and stakeholder.

The number of board of commissioners in a company must be able to guarantee that the supervision mechanism runs smoothly and in accordance with applicable laws and regulations. One of the independent commissioners must have accountant and financial background [3]. About the number of independent commissioners regulated in OJK Regulation No.33/POJK.04/2014 which is the number of independent commissioners must be at least $30 \%$ from all the number of the boards of commissioners. Research that conducted by Agustiningsih et al., independent commissioners' proportion in the boards of commissioners' composition measured by using number of proportions of independent commissioners to all members of commissioners [2]. Boards of independent commissioners measured and determined by number of proportions of independent commissioners. Boards of Independent Commisioner $=\frac{\text { Number of Independent Commisioners }}{\text { Number of Commisioners }}$

\section{6) Boards of Directors}

OJK Regulation about directors and boards of commissioner's issuers or public company, defined directors as the part of issuer or public company that full authorized and responsible to issuer or public company management for issuer or public company interest, corresponding to the purpose and objective of the issuer or public company and represent issuer or public company, both outside or inside the court correspondent to basis provisions costs [17]. Directors member appointed and dismissed by General Meeting of Shareholder (RUPS) with a 5 years length of services or until the yearly closing of RUPS in the end if length of service period. The director's duty regulated in Regulation about director and boards of commissioners' issuer or public company, such as [17]:

1. Commissioners be in charge on supervising and responsible to management policy and the way management is done, related to issuer or issuer business and giving advice to director.

2. Commissioners must conduct yearly RUPS and another RUPS in certain condition.

3. Member of commissioners must supervise to the way the management is done that related to issuer with good will, responsible, and carefully.
4. Commissioners must make audit committee and another committee to support the effectiveness of their duty and responsibilities.

5. Commissioners must evaluate the committee performance that they have made in terms of assisting the implementation of their duties and responsibilities at the end of each financial year.

Every member of director can do their job and making decision according to their division of tasks and authority. But, the duties implementation of each director still become all director's responsibility. National Committee on Governance Policy explaining the principals that must be fulfilled by board of directors so that the duty that became their responsibilities can run smoothly in effective ways such as [3]:

1. Director composition must adjust to company complexity so making effective, right, and fast decision can be possibly done and can act independently.

2. Director must be professional, have integrity and have experience and skill that needed to done their duty.

3. Director responsible to company management that can make profit and make sure of company business continuity.

4. Director account for their management in RUPS accordance with applicable laws.

Research that conducted by Kusuma and Supatmi, boards of directors measured by using number of member of boards of director in a company [5]. Director member in a company at least 2 persons, which once of them will be appointed as president director. Boards of directors measured by determining number of member of boards of director in a company.

\section{Boards of Directors $=$ Number of Board of Director Members}

\section{7) Institutional Ownership}

Institutional ownerships are company shareholding that owned by external party such as institution like another company, insurance, bank, and investment company. According to Kusuma and Supatmi institutional ownerships is number of stock percentage that owned by institution that obtained from addition percentage of stock that owned by another company both domestic or overseas, also the addition of stock that owned by government both domestic or overseas [5]. At the same time, according to Setiawan institutional ownerships is institute stakeholder or government that not active in company operation activities [15]. Institution is a professional decision maker that know how to measure the company's financial performance and know how to supervise the management. The existence of institutional investor can show the strong implementation of good corporate governance also can be used as a tool to monitored the company management.

Institutional ownership beside their function as management monitoring tool, have another function as controller to the company to create good performance. Beside that, institutional ownership can reduce agency problem in the company. That happen because the higher of institutional ownership will causing bigger supervising by institutional 
The $1^{\text {st }}$ International Conference on Business and Engineering Management (IConBEM)

February $1^{\text {st }} 2020$, Institut Teknologi Sepuluh Nopember, Surabaya, Indonesia

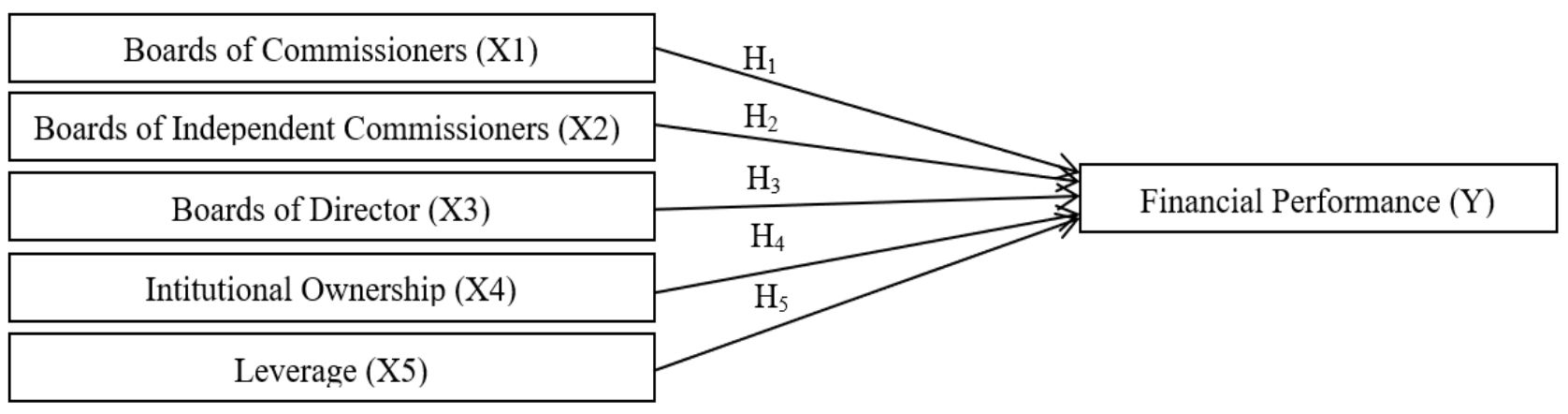

Figure 1. Framework

investor, so that can expect to reduce the misappropriations that done by company management. Misappropriation that done by company management worried will impact to decreasing of company value. The higher of institutional ownership will causing bigger supervising by institutional investor, so can make more pressure to optimizing company value, so the performance will be increased. Research that done by Ratih and Setyarini argued that institutional ownership measured by the stock percentage that owned by institution divided by number of circulating stocks [7].

Institutional Ownership $=\frac{\text { Number of stock owned by institution }}{\text { Number of circulating stock }}$

\section{8) Leverage}

The capital structure of a company consists of debt, equity, or a mixture of debt and equity. Proportion of debt in the capital structure known as leverage. According to Abubakar leverage is how far the company can take advantage of debt in capital structure [9]. Leverage shown the proportion of usage of debt to pay their infestation so it taking part in order to increase the performance of company financial [4]. Leverage definition according to Makhdalena is a standard to see how many assets that owned by the company that paid using debt [10]. Debt will be causing monitoring by bondholders and debt will reduce excess cash flow that happened in the company so that will reducing dissipation by the management.

Financial leverage is an important and significant decision that taken by manager because the decision have an important implication to company's financial performance. Financial leverage is the alternative that can be used to increasing profits [4]. Proportion of using debt in infestation as additional to paid company assets is expected to increase profits of the company, so that profits will generate the bigger profits. But the highest debt proportion in capital structure risking the company experiencing risk of default that will be causing to financial trouble and bankruptcy.

The high proportion of debt in capital structure of the company showed that the company must pay off to the primary loan and the interest. Debt interest is not taxed, so that the company can use debt in capital structure to take an advantage as reducing tax that must be paid. Usage of debt in capital structure can be used to disciplined the manager also because of agency problem. There is certain benefits and costs related to usage of debt, so that the manager must give benefits to increase company financial performance from decision for taking a debt. Kasmir explains that there are several ratios that can be used to measure leverage [18]:

a. Debt to asset ratio $=\frac{\text { Total debt }}{\text { Total assets }}$

b. Debt to equity ratio $=\frac{\text { Total utang (Debt) }}{\text { Ekuitas (Equity) }}$

c. Long Term Debt to Equity Ratio $=\frac{\text { Long term debt }}{\text { Equity }}$

d. Times Interest Earned

Times Interest Earned $=\frac{\text { EBIT }}{\text { Biaya bunga (Interest) }}$

Time Interest Earned $=\frac{\text { EBT }+ \text { Biaya bunga }}{\text { Biaya bunga (Interest) }}$

e. Fixed charge coverage $=\frac{\text { EBT }+ \text { Biaya bunga }+ \text { Kewajiban sewa }}{\text { Biaya bunga }+ \text { Kewajiban sewa }}$

\section{METHODS}

This is a conceptual and qualitative research. This research reviewing 12 previous research that discuss about the impact of good corporate governance and leverage to financial performance.

\section{RESULT AND DISCUSSION}

According to theory explanation and previous research, the framework that used in this research is is shown in Figure 1.

\section{A. The Effect of Boards of Commissioners to Financial Performace}

Boards of commissioner is a part of the company that appointed and dismissed by RUPS that officiate, responsible, have an authority to supervising and giving advice to the director and make sure that the company is implementing good corporate governance, so that the boards of commissioners was expected to increase financial performance and break the agency problem that happen in company management. The more commissioners inside a company, then it will more increasing company's performance. That because the effective monitoring that done by a lot of people, so that can minimize misappropriation by the management. That prove that the commissioners have important role in increasing the effectivity of company's operation that effected to increasing company's financial performance. The impact of commissioners to financial performance was supported by previous research by 
The $1^{\text {st }}$ International Conference on Business and Engineering Management (IConBEM)

February $1^{\text {st }} 2020$, Institut Teknologi Sepuluh Nopember, Surabaya, Indonesia

Agustiningsih et al, explaining that the bigger size of commissioners will easier they duty on supervising the management and the director [2]. Monitoring function will be easier because its bigger size so the monitoring can be divided to members so can be focus on supervising every part. Therefore, monitoring function will be more effective, so can push the company ability to increase their financial performance.

\section{B. The Effect of Boards of Independent Commissioners to Financial Performace}

Independent commissioners is the member of boards of commissioner which come from the outside of issuer or public company that have no financial, management, shareholder, and family relation to another commissioners members, director, stakeholder, that effecting their duty to act independently. Independent commissioners are neutral function, where the independent commissioners have duty and responsibility as supervisory board after the commissioner. Independent commissioners in a company not allowed to stand with any party, so their existence can reduce misappropriation by the management and can give a plus to all stakeholder of the company. The existence of independent commissioners also expected to minimize the agency problem and increasing the effectivity of management performance that will impact to financial performance. The more proportion of independent commissioners in a company, the duty and function of commissioners in implementation of corporate governance principals will be more effective, especially in independency and fairness [2]. That can be happen because the independent commissioner believed as not having any interest conflict with the company. The effect of independent commissioners to the financial performance supported by research that conducted by Agustiningsih et al., that found that independent commissioner has significant effect to company's financial performance [2].

\section{The Effect of Boards of Directors to Financial Performace}

Board of director based on OJK Regulation about directors and boards of commissioner's issuers or public company, defined directors as the part of issuer or public company that full authorized and responsible to issuer or public company management for issuer or public company interest, corresponding to the purpose and objective of the issuer or public company and represent issuer or public company, both outside or inside the court correspondent to basis provisions costs [17]. Director as the part of company officiate and responsible to manage the company. If their role and function running as well, the management will be more careful in operating activities that can affected the financial performance time by time. More director in a company the supervising will be better as well. Company performance that have ben controlled will make good profitability and affected to company's financial performance. The effect of independent director to the financial performance was supported by Nurcahya et al., that the result found that the director has significant effect to company's financial performance [4].

\section{The Effect of Intitutional Ownership to Financial Performace}

Institutional ownerships are company shareholding that owned by external party such as institution like another company, insurance, bank, and investment company. The existence of institutional investor can show the strong implementation of good corporate governance also can be used as a tool to monitored the company management and become the controller to them to create better performance. Also, the institutional ownership can reduce the agency problem in a company. The higher of institutional ownership will causing bigger supervising by institutional investor, so can give more encouragement to optimized company value, so the performance will be increased. Institutional investor can have important role in taking strategic decision, they are rightfully choosing the director and have a right to vote in RUPS. Because of that, can be said that institutional ownership effected to infestation return in company assets. The effect of director to financial performance supported by previous research by Wijaya et al., and Ratih get the result that institutional ownership has positive impact to financial performance [6], [7].

\section{E. The Effect of Leverage to Financial Performace}

Leverage is how far the company can take advantage of debt in capital structure. Leverage shown the proportion of usage of debt to pay their infestation so it taking part in order to increase the performance of company financial. Debt will be causing monitoring by bondholders and debt will reduce excess cash flow that happened in the company so that will be reducing dissipation by the management. Proportion of using debt in infestation as additional to paid company assets is expected to increase profits of the company, so that profits will generate the bigger profits, so that the profit that available for stakeholder will be bigger as well. So, it can be said that leverage has an impact to company financial performance. But the highest debt proportion in capital structure risking the company experiencing risk of default that will be causing to financial trouble and bankruptcy. The high proportion of debt in capital structure of the company showed that the company must pay off to the primary loan and the interest. Usage of debt in capital structure can be used to disciplined the manager also because of agency problem. There is certain benefits and costs related to usage of debt, so that the manager must give benefits to increase company financial performance from decision for taking a debt. The effect of leverage to financial performance supported by previous research by Musah and Koh; Abubakar and Garba; Tampubolon; and Nurcahya et al., that the result found says leverage has an impact to financial performance [4], [8], [14], [16]. The research that conducted by Abubakar said that leverage has a negative impact to financial performance, and the research by Makhdalena found that leverage has an insignificant negative impact to financial performance [9], [10]. 
The $1^{\text {st }}$ International Conference on Business and Engineering Management (IConBEM)

February $1^{\text {st }} 2020$, Institut Teknologi Sepuluh Nopember, Surabaya, Indonesia

\section{CONCLUSSION}

From the discussion above about basis theory and previous research, reader can conclude that good corporate governance that consist of commissioners, independent commissioners, directors, institutional ownerships as non-financial aspect and leverage as financial aspect have impact to company financial performance. According to the analysis of previous research, this research found some proposition:

1. Boards of commissioners has impact to financial performance.

2. Boards of independent commissioners has impact to financial performance.

3. Boards of director has impact to financial performance.

4. Institutional ownership has impact to financial performance.

5. Leverage has impact to financial performance

Because this is a conceptual research, so this research has some limitation such as limited depth of discussion. Even this research was presenting the concept of good corporate governance and leverage, researcher suggested that good corporate governance and leverage must have further studies in order to obtain further results and studies. This research have two recomendations :

1. Recommendations for trying to carry out further quantitative research using specific sectors, for example the manufacturing sector, property sector, and other sectors

2. Recommendations for adding other variables in measuring good corporate governance

This research have two impact to :

1. Student : this research can be used as an additional discourse, reference, and literature for subsequent research related to the company's financial performance

2. Stakeholder : This research can be used as a consideration for making decisions and adding information

\section{ACKNOWLEDGMENTS}

I would like to thank the lecturers of STIE Perbanas Surabaya who have provided criticism and suggestions in the preparation of this research. I also wouldlike to thank International Conference on Business and Engineering Management 2020 (IConBEM 2020) for giving me the opportunity to publish this research. Not to forget, I would like to thank my all family for always supporting me.

\section{REFERENCES}

H. Hartoyo, "Hubungan current ratio, struktur modal, dan ukuran perusahaan terhadap kinerja keuangan perusahaan pertambangan yang terdaftar di BEI periode 2014-2016," J. Maksipreneur Manajemen, Koperasi, dan Entrep., vol. 8, no. 1, pp. 81-97, 2018, doi: 10.30588/jmp.v8i1.375.

[2] S. W. Agustiningsih, C. R. Sulistyaningsih, and P. Purwanto, "Pengaruh penerapan corporate governance terhadap kinerja keuangan perusahaan di Indonesia," J. Akunt. dan Bisnis, vol. 16, no. 1, p. 36, 2016, doi: 10.20961/jab.v16i1.188.

[3] Komite Nasional Kebijakan Governance, Pedoman Umum Good Corporate Governace Indonesia. Jakarta, Indonesia: Komite Nasional Kebijakan Governance, 2006.

[4] A. S. Nurcahya, E. D. Wahyuni, and S. Setyawan, "Pengaruh good corporate governance, ukuran perusahaan dan leverage terhadap kinerja keuangan perusahaan," J. Reviu Akunt. dan Keuang., vol. 4, no. 1, 2017, doi: 10.22219/jrak.v4i1.4931.

[5] E. M. Kusuma and S. Supatmi, "Hubungan mekanisme corporate governance dan kinerja keuangan Bank Pembiayaan Rakyat Syariah," J. Ekon. dan Bisnis, vol. 18, no. 3, p. 118, 2016, doi: 10.24914/jeb.v18i3.282.

[6] R. Wijaya, A. Rohman, and Z. Zulaikha, "The effect of good corporate governance on financial performance and net working capital turnover as a mediation variable: Evidence from Indonesia Stock Exchange (IDX)," J. Bus. Retail Manag. Res., vol. 13, no. 1, pp. 70-80, 2018, doi: 10.24052/JBRMR/V13IS01/ART-07.

[7] S. Ratih and Y. Setyarini, "Pengaruh Good Corporate Governance (GCG) dan Corporate Social Responsibility (CSR) terhadap nilai perusahaan dengan kinerja keuangan sebagai variable intervening pada perusahaan pertambangan yang go public Di BEI," AKRUAL J. Akunt., vol. 5, no. 2, p. 132, 2014, doi: 10.26740/jaj.v5n2.p115132.

[8] L. D. Tampubolon, “Analisis pengaruh rasio keuangan: Likuiditas, aktivitas dan leverage terhadap penilaian kinerja keuangan studi empiris: Perusahaan manufaktur di Bursa Efek Indonesia periode 2010 - 2012," J. Keuang. dan Perbank., vol. 12, no. 1, pp. 1-12, 2016.

[9] A. Abubakar, "Financial leverage and financial performance of quoted industrial goods firms in Nigeria," KASU J. Manag. Sci., vol. 18 , no. 2 , pp. 89-108, 2017.

[10] M. Makhdalena, "Pengaruh blockholders ownership, fiem size, and leverage terhadap kinerja keuangan perusahaan," EKUITAS (Jurnal Ekon. dan Keuangan), vol. 18, no. 3, pp. 277-292, 2018, doi: 10.24034/J25485024.Y2014.V18.I3.136.

[11] M. C. Jensen and W. H. Meckling, "Theory of the firm: Managerial behavior, agency costs and ownership structure," J. financ. econ., vol. 3, no. 4, pp. 305-360, 1976, doi: 10.1016/0304405X(76)90026-X.

[12] S. C. Myers, "Capital Structure," J. Econ. Perspect., vol. 15, no. 2, pp. 81-102, 2001, doi: 10.2307/2696593.

[13] E. F. Brigham and J. F. Houston, Dasar-dasar Manajemen Keuangan. Jakarta, Indonesia: Salemba Empat, 2011.

[14] A. Abubakar and A. Garba, "Financial leverage and financial performance of quoted services firms in Nigeria," Niger. J. Manag. Technol. Dev., vol. 8, no. 2, pp. 273-282, 2019.

[15] A. Setiawan, "Pengaruh corporate governance terhadap kinerja keuangan perusahaan," J. SIKAP (Sistem Informasi, Keuangan, Audit. Dan Perpajakan), vol. 1, no. 1, p. 8, 2016, doi: 10.32897/jsikap.v1i1.41.

[16] M. Musah and Y. Kong, "Leverage and financial performance: The correlational approach," Int. J. Innov. Res. Multidiscip. F., vol. 5, no. 4, pp. 1-8, 2019.

[17] Peraturan Otoritas Jasa Keuangan Nomor 33/PJOK.04/2014 tentang Direksi dan Dewan Komisaris Emiten atau Perusahaan Publik. .

[18] K. Kasmir, Analisa Laporan Keuangan. Jakarta, Indonesia: Rajawali Pers, 2013. 